\title{
Genetic Diversity in Haploid Nicotiana alata Induced by Gamma Irradiation, Salt Tolerance and Detection of These Differences by RAPD
}

\author{
Ayman EL-FIKI ${ }^{1 *}$, Abdel-Hadi SAYED ${ }^{2}$, Gamal EL-METABTEB ${ }^{1}$, Mohamed ADLY ${ }^{1}$ \\ ${ }^{1}$ National Centrefor Radiation Research and Technology, Nasr City, Cairo, Egypt; aymana.elfiki@eaea.org.eg(*corresponding author); \\ gamalelmetabteb@yahoo.com;adly4000@yahoo.com \\ ${ }^{2}$ Al-Azhar University, Faculty of Agriculture, Cairo, Egypt; a sayed@fastmail.fm
}

\begin{abstract}
Haploid plants of Nicotiana alata were cultured in vitro on MS medium with IAA + KIN. The resulting plantlets were irradiated using gamma radiation doses of 10, 15, 20 and 25 Gy. Single node pieces were cut and transferred onto fresh MS medium. Gamma radiation doses caused the death of $9 \%$ and up to $28 \%$ of explants. $\mathrm{NaCl}$ concentrations caused the death of $8 \%$ up to $36 \%$ of explants, while the combined effect between gamma radiation doses and salinity had an impact suffused on the percentage of survival. The combined effect of gamma radiation doses $20 \mathrm{~Gy}$ and $25 \mathrm{~Gy}$ on $\mathrm{NaCl}$ concentrations of 100, 150 and $200 \mathrm{mM}$ were deadly. Even more, the combined effect of gamma radiation doses and salinity had a severe negative impact on both the proline content and total soluble protein. Random amplified polymorphic DNA (RAPD) analysis was used to determine the degree of genetic variation in treated haploid Nicotiana alata plants. Total genomic DNAs from different haploid plantlets treated were amplified using five arbitrary primers. Two hundred and seventy bands were detected from plantlets irradiated with doses of 15, 20 and $25 \mathrm{~Gy}$, with polymorphic band number 226 (83.7\%). The total number of bands resulted from plant grew on $150 \mathrm{mM}$ and $200 \mathrm{mM} \mathrm{NaCl}$ were 260 bands with polymorphic bands 185 (85.6\%). However, the total number of bands produced from combined effects between gamma rays and salinity (20 Gy X $50 \mathrm{mM} \mathrm{NaCl}, 20 \mathrm{~Gy}$ X $100 \mathrm{mM} \mathrm{NaCl}$ and $25 \mathrm{~Gy}$ X $50 \mathrm{mM} \mathrm{NaCl}$ ) were 270, with polymorphic band number 231 (85.5\%). High similarity between treatments was revealed. Treatments relationships were estimated through cluster analysis (UPGMA) based on RAPD data.
\end{abstract}

Keywords: microcutting, Nicotiana alata, radiation, RAPD, salinity, stress

\section{Introduction}

Nicotiana genus is one of the five major genera of the Solanacae family. Nicotiana sp. has been cultivated for thousands of years and served as a medicinal herb, trade commodity and crop plant by different cultivars. Nowadays, it became one of the most important commercial crops in the world. Within the past several decades, it was found yet another use of the genus, serving as a widely utilized model system in plant cell culture and genetic engineering research (Zhang et al., 2007). Because of its economic importance and the value as biological research tool, numerous investigations have been undertaken to examine its evolutionary origin and genome structure and organization.

Salinity in soil or water is one of the major abiotic stresses that reduce plant growth and crop productivity worldwide. More than 800 million hectares of land throughout the world are salt-affected (including both saline and sodic soils), equating to more than $6 \%$ of the world's total land area (FAO, 2008). Some of the most serious examples of salinity occur in the arid and semiarid regions. For example, in Iran, Pakistan, Egypt and Argentina, out of the total land area of 162.2, 77.1, 99.5 and 237.7 million hectares, about 23.8, 10, 8.7 and 33.1 million hectares are salt-affected, respectively (FAO, 2008). Low rainfall, high evaporation, native rocks, saline irrigation water and poor water management increasingly cause salinity problems in agricultural areas. It is estimated that of the current 230 million hectares of land under irrigation, 45 million hectares are salt-affected (20\%) and of the 1,500 million hectares of dry land agriculture, 32 million hectares (2\%) are salt-affected (FAO, 2008). Overall, it was estimated that the world is losing at least 3 ha of arable land every minute because of soil salinity (FAO, 2008).

Salinity is one of the most severe environmental factors limiting the productivity of agricultural crops. Most crops are sensitive to salinity caused by high concentrations of salts in the soil. The cost of salinity to agriculture is estimated to high values and is expected to increase as soils are further affected (Ghassemi et al., 1995). In addition, to this enormous financial cost of production, there are other serious impacts of salinity on infrastructure, water supplies and on social structure and stability of communities.

Responses to salinization have been of two general kinds; engineering the environment to manage increased salt in the soil by irrigation and drainage management, or by "engineering" the plants to increase their salt tolerance. Salt tolerant plants may also ameliorate the environment by lowering the water table in salt affected soils.

Gamma rays belong to ionizing radiation and interact to atoms or molecules to produce free radicals inside treated cells. 
74

These radicals can damage or modify important components of plant cells and have been reported to affect differentially the morphology, anatomy, biochemistry and physiology of plants, depending on the irradiation level. These effects include changes in the plant cellular structure and metabolism, e.g. dilation of thylakoid membranes, alteration in photosynthesis, modulation of the antioxidative system and accumulation of phenolic compounds (Kovacs and Keresztes, 2002; Kim et al., 2004; Wi et al., 2005).

Molecular genetic markers have become useful tools in providing a relatively unbiased estimation of genetic diversity and phylogeny in plants (Clegg, 1990). Several different PCR techniques for DNA fingerprinting have been developed during the last decades, each one with specific advantages and disadvantages. Random amplified polymorphic DNA (RAPD) is the simplest and fastest of DNA-based techniques in genetic similarity studies (Gwanama et al., 2002). A number of scientists have used RAPD markers to study polymorphism in various plants (Ortiz et al., 1997; Ranade et al., 2002; Rout and Das, 2002; Samal et al., 2003). In tobacco, RAPD has been used mainly to identify markers linked to genes for resistance to pathogens (Bai et al., 1995; Rufty, et al., 1997; Yi et al., 1998).

The aim of the present study was to investigate the induction of genetic variability using gamma radiation and selection for salt tolerance based on the similarity of the RAPD technique data, undertaken to distinguish Nicotiana alata diploid and haploid plants treated with gamma radiation and/ or salinity and to detect genetic diversity among them.

\section{Materials and Methods}

Nicotiana alata haploid plants obtained from anther culture (El-Fiki et al., 2015) were cultured on MS medium (Murashige and Skoog, 1962) supplemented with $0.2 \mathrm{mgl}^{-1}$ IAA + $0.5 \mathrm{mgl}^{-1}$ KIN. Micropropagation began after 4-5 weeks, when the plantlets reached $5 \mathrm{~cm}$ height. The culture was maintained by cutting into single nodes. The $\mathrm{pH}$ of the culture medium was adjusted to 5.7 before autoclaving and incubated inside a growth chamber at $25 \pm 2{ }^{\circ} \mathrm{C}$ under photoperiod of $16 \mathrm{~h}$.

Irradiation was carried out with a ${ }^{60} \mathrm{Co}$ source at National Centre for Radiation Research and Technology, Atomic Energy Authority, Cairo, Egypt. Mass cultures of in vitro grown plantlets derived from single nodes were irradiated with different doses of gamma rays $(10,15,20$ and 25 Gy). Thus, 800 in vitro grown plantlets were irradiated with gamma rays at each dose.

For the selection of salt tolerance after irradiation, the single node pieces were transferred onto MS medium supplemented with 50,100, 150 and $200 \mathrm{mM} \mathrm{NaCl}$. The survival of single node cuttings was recorded after 40 days of culture.

\section{The proline content}

Proline content was estimated according to Batels et al. (1973) for plantlets grown on saline medium, irradiated plantlets and the plantlets grown under combined effects between gamma radiation and salinity.

\section{The total soluble protein}

The plantlets grown on saline medium, irradiated plantlets and the plantlets grown under combined effects between gamma radiation and salinity were estimated according to Bradford (1976).

\section{Extraction of genomic DNA}

Thirty days old plantlets of each diploid and haploid plants were collected, bulked and frozen in liquid nitrogen. Plantlets were ground to fine powder and then bulked DNA extraction (QIAGEN) was under taken and quantified on $0.8 \%$ agarose gel.

\section{RAPD amplification}

Five different primers were chosen arbitrarily. The primers used in the current experiment were 10-mer synthesized by Operon biotechnologies (Inc. Germany). Primers sequences (5' 3') were as follows: Op-C13: AAGCCTCGTC, Op-Do7: GGACCCAACC, Op-I15: AAGAGAGGGG, Op-L12: GGGCGGTACT, Op-M20: GTTGGTGGCT. Amplification reactions were performed in a $25 \mu \mathrm{l}$ volume, containing: $20 \mathrm{mM}$ Tris-HCl (pH 8.4), $50 \mathrm{mM} \mathrm{KCl,} 2.5 \mathrm{mM}$ $\mathrm{MgCl}_{2}, 200 \mu \mathrm{M}$ each of $\mathrm{dNTPs}, 1 \mu \mathrm{M}$ primer, $30 \mathrm{ng}$ of genomic DNA, 1.5 U of Taq DNA polymerase. The reaction mixture was overlaid with two drops of mineral oil, incubated for $5 \mathrm{~min}$ at 95 ${ }^{\circ} \mathrm{C}$ for initial denaturation, and then amplified for 35 cycles consisting of 30 s at $94^{\circ} \mathrm{C}, 30$ s at $36^{\circ} \mathrm{C}$ and 60 s at $72^{\circ} \mathrm{C}$, followed by $7 \mathrm{~min}$ incubation at $72{ }^{\circ} \mathrm{C}$. Amplification products were separated by gel electrophoresis on precast $0.8 \%$ agarose and visualized under UV illumination after staining with ethidiam bromide and photographed.

\section{Data analysis}

The size of RAPD fragments were estimated by comparison with the marker. RAPD fingerprints were recorded in the binary form $(1=$ presence of a band and $0=$ absence of a band $)$. All data were scored twice by two independent scorings. A simple matching coefficient was calculated to construct a similarity matrix and the UPGMA algorithm was used to perform hierarchical cluster analysis and to construct a dendrogram by using NTSYS-pc package (Rohlf, 1990).

\section{Results and Discussion}

Data in Table 1 summarizes the effect of gamma radiation, $\mathrm{NaCl}$ concentrations and the combined effect between them on the percentage of microcuttings survival and shoot length.

Gamma irradiation doses of 10, 15, 20 and 25 Gy caused a decrease in the survival percent of micropropagated buds to 87 , 81, 74 and $68 \%$ respectively. The irradiation doses had a negative impact on shoot length as shown in Fig. 1, where the shoot length decreased

with increasing gamma radiation dose $(5.1,4.5,3.9$ and $3.2 \mathrm{~cm}$ respectively). The results showed by the radiation sensitivity test, based on survival percentage of irradiated and nonirradiated plantlets, showed a significant reduction in survival percentage as observed with increasing gamma dosage. These results were in accordance with radiation sensitivity test done by Hasegawa et al. (1995) for tobacco, El-Fiki (1997) for potato, El-Fiki et al. (2005a and b) for alfalfa, Norfadzrin et al. (2007) for tomato and okra and Kiong et al. (2008) for Orthosiphon stamineus. 
Table 1. Effect of gamma irradiation and salinity concentration on Nicotiana alata buds survival

\begin{tabular}{|c|c|c|c|c|c|c|c|c|c|c|}
\hline \multirow{3}{*}{$\begin{array}{c}\mathrm{NaCl} \\
\text { conc/mM }\end{array}$} & \multicolumn{10}{|c|}{ Radiation dose/Gy. } \\
\hline & \multicolumn{2}{|c|}{0} & \multicolumn{2}{|c|}{10} & \multicolumn{2}{|c|}{15} & \multicolumn{2}{|c|}{20} & \multicolumn{2}{|c|}{25} \\
\hline & $\begin{array}{c}\text { Bud } \\
\text { survival (\%) }\end{array}$ & $\begin{array}{c}\text { Shoot } \\
\text { length }(\mathrm{cm})\end{array}$ & $\begin{array}{c}\text { Bud } \\
\text { survival (\%) }\end{array}$ & $\begin{array}{c}\text { Shoot } \\
\text { length }(\mathrm{cm})\end{array}$ & $\begin{array}{c}\text { Bud } \\
\text { survival (\%) }\end{array}$ & $\begin{array}{c}\text { Shoot } \\
\text { length }(\mathrm{cm})\end{array}$ & $\begin{array}{c}\text { Bud } \\
\text { survival (\%) }\end{array}$ & $\begin{array}{c}\text { Shoot } \\
\text { length }(\mathrm{cm})\end{array}$ & $\begin{array}{c}\text { Bud } \\
\text { survival (\%) }\end{array}$ & $\begin{array}{c}\text { Shoot } \\
\text { length }(\mathrm{cm})\end{array}$ \\
\hline 0.0 & 96 & 10.2 & 87 & 5.1 & 81 & 4.5 & 74 & 3.9 & 68 & 3.2 \\
\hline 50 & 88 & 6.6 & 80 & 5.1 & 64 & 4.7 & 52 & 3.5 & 36 & 2.0 \\
\hline 100 & 76 & 5.3 & 72 & 4.3 & 56 & 3.8 & 44 & 2.6 & 0 & 0 \\
\hline 150 & 68 & 4.6 & 60 & 3.8 & 48 & 3.1 & 0 & 0 & 0 & 0 \\
\hline 200 & 60 & 3.9 & 48 & 3.2 & 40 & 2.8 & 0 & 0 & 0 & 0 \\
\hline $\operatorname{LSD}(5 \%)$ & & 0.76 & & 0.39 & & 0.62 & & 0.34 & & 0.11 \\
\hline
\end{tabular}

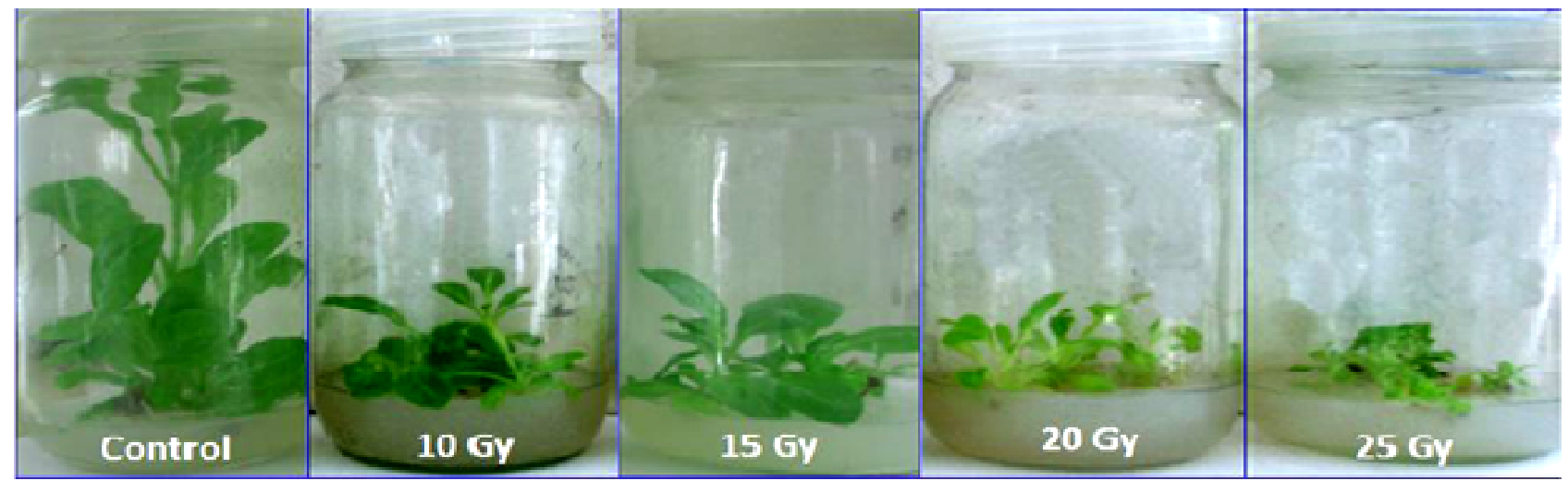

Fig. 1. Effect of gamma radiation doses on Nicotiana alata haploid plants survival in Nicotiana alata

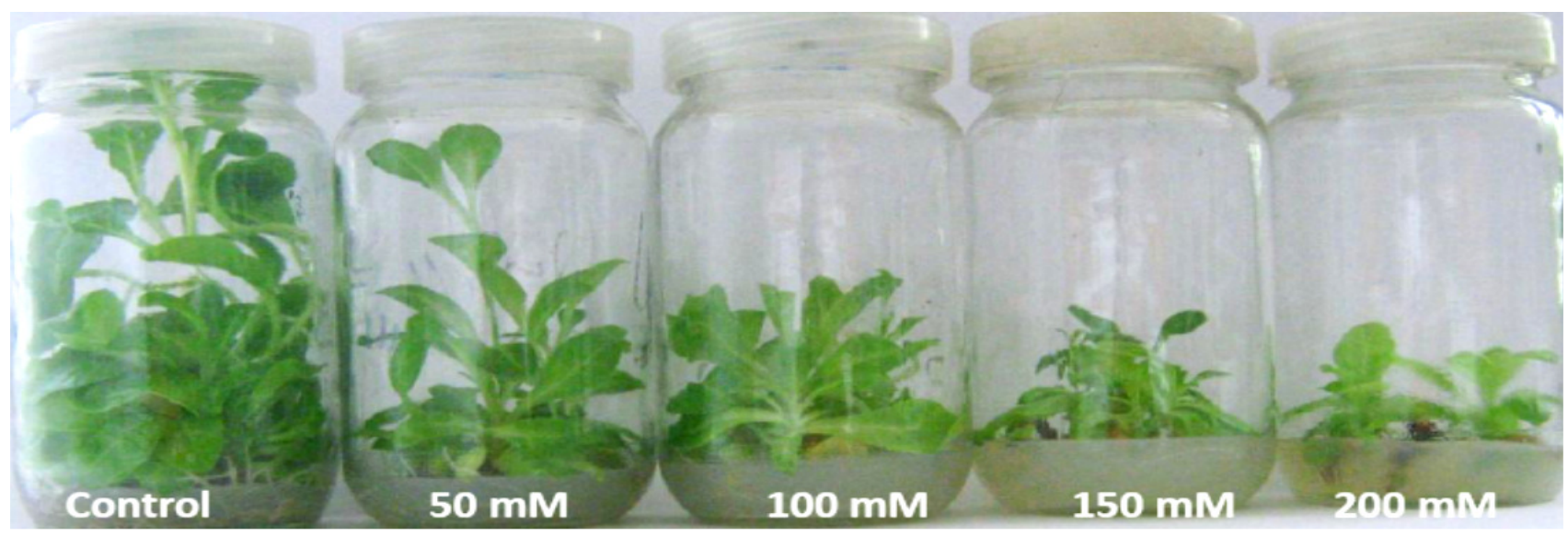

Fig. 2. Effect of $\mathrm{NaCl}$ concentrations on Nicotiana alata haploid plants survival in Nicotiana alata

The survival percent of single node buds grown on a medium containing different concentrations of $\mathrm{NaCl}(50,100$, 150 and $200 \mathrm{mM}$ ) decreased to 88, 76, 68 and $60 \%$ respectively. As shown in Fig. 2, the $\mathrm{NaCl}$ caused decreasing in shoot length with increasing $\mathrm{NaCl}$ concentrations $(6.6,5.3,4.6$ and $3.9 \mathrm{~cm}$ respectively). The results showed by the salinity sensitivity test on survival percentage of plantlets grown on saline medium and control ones emphasize a significant reduction in survival percentage as observed with increasing $\mathrm{NaCl}$ concentration.

Environmental abiotic stresses, such as drought, extreme temperatures, or high salinity, severely compromise plant growth and development. Water availability is one of the major factors affecting crop-yield worldwide. Many irrigated areas are poorly drained so that additionally, serious problems of waterlogging, alkalinization and soil salinity are frequent. Research on the two major abiotic stresses, drought and salinity, have much in common. Salinity reduces the ability of plants to take up water, which quickly causes a reductions in growth rate along with metabolic changes identical to those caused by water stress. Unfortunately, the complexity and polygenic nature of drought and salt stress tolerance make it difficult to select these characters in conventional breeding programs. Abiotic stresses induce morphological, biochemical and physiological changes in plants during the acquisition of stress tolerance. At the cellular level, water deficit may cause cellular damage or initiate adaptive responses (Cellier et al., 1998). The products of stress-inducible genes can be classified into two groups (Bray, 1997; Hasegawa et al., 2000): (i) genes that directly protect against stress, (ii) genes that regulate gene expression and signal transduction in the stress response. A large number of genes have been linked to stress response pathways although their precise functions often remain unclear (Zhu, 2000). Many salt-responsive genes do not increase tolerance, but induce stress damage and genes important for salt tolerance may not be expressed during salt stress. However, 
76

the genomic drought and salt stress responses both reflect the necessity for cellular protection by free-radical scavengers, chaperonins and regulators of redox and osmotic potential (Hasegawa et al., 2000).

The combined effect of different gamma radiation doses and $\mathrm{NaCl}$ concentrations on the percentage of microcutting survival and shoot length were decreased within all combinations. As shown in Table 1 the gamma radiation dose of $20 \mathrm{~Gy}$ had a fatal effect on survival of buds grown on medium containing 150 and $200 \mathrm{mM} \mathrm{NaCl}$. The effect of gamma radiation dose $25 \mathrm{~Gy}$ caused mortality on microcutting survival buds grown on medium containing 100, 150 and 200 $\mathrm{mMNaCl}$.

Low and high temperatures, salinity and water availability severely reduced grain yields in agricultural systems (Grant $e t$ al., 1989). Stress tolerance in plants is a complex trait and direct selection for grain yield under stress conditions has been hampered by low heritability, polygenic control, epistasis and high genotype-by-environment $(\mathrm{G} \times \mathrm{E})$ interactions. Early plant responses to environmental stresses include gens involved in perception of the environmental change and signal transduction to initiate biochemical and physiological responses, together with expression of the genes responsible for these responses. These results could be explained by the existence of a high interaction between the genotype and environmental conditions.

Radiation treatment increased the variability in the genetic background of the variety rather than changing the gene expression. The variability in the presence of $\mathrm{NaCl}$ may be due to the interaction between the mutagen and the selection medium.

\section{Proline content}

Data in Table 2 illustrated that the Nicotiana alata haploid plants have been influenced by exposure to different doses of gamma rays, as proline content increased with increasing gamma radiation dose. As well, proline content increased with increasing $\mathrm{NaCl}$ concentration. However, the combined effect between gamma radiation doses and $\mathrm{NaCl}$ concentrations on proline content had a negative impact.

\section{Total solubleprotein}

Total soluble protein was estimated in Nicotiana alata haploid plant as shown in Table 3. The irradiated plantlets with gamma radiation doses had the total soluble protein increased with increasing gamma radiation dose. As well, plants that have been exposed to different concentrations of salinity were found to have increased total soluble protein content with increasing $\mathrm{NaCl}$ concentration. However, the combined effect of gamma radiation doses and salinity had a negative impact on plants' total soluble protein.

Table 2. The combined effects of gamma radiation doses and $\mathrm{NaCl}$ concentrations on proline contents ( $\mathrm{mg} / 100 \mathrm{gm}$ fresh wt.) in haploid Nicotiana alata plants

\begin{tabular}{cccccc}
\hline \multirow{2}{*}{$\begin{array}{c}\mathrm{NaCl} \\
\text { conc/mM }\end{array}$} & 0 & 10 & 15 & 20 & 25 \\
\cline { 2 - 6 } & 0.18 & 1.09 & 1.13 & 1.23 & 1.25 \\
5.0 & 1.55 & 0.55 & 0.89 & 0.99 & 1.05 \\
100 & 1.61 & 0.71 & 0.95 & 1.06 & 0 \\
150 & 1.71 & 0.77 & 0.99 & 0 & 0 \\
200 & 1.88 & 0.83 & 1.08 & 0 & 0 \\
\hline
\end{tabular}

The physiological and biochemical changes in plant tissue in response to different types of osmotic stresses are not completely understood. Stress effects on plant cells and tissues were investigated and the stress inducing compounds used in different experiments were both ionic and penetrating (e.g. $\mathrm{NaCl}$ ), non-ionic and penetrating (e.g. mannitol, sorbitol etc.) or non-ionic and non-penetrating (e.g. polyethylene glycol). Results of such experiments, however, have shown the following general trends in the plant tissues: (1) retardation of growth (Binzel et al., 1985; Rains, 1989; Kumar and Sharma, 1989; Thomas et al., 1992); (2) acquisition of the ability to adapt to stressful environments (Lerner, 1985; Binzel et al., 1985; Handa et al., 1986; Fallon and Phillips, 1989); and (3) accumulation of proline at a high level (Yancey et al., 1982; Watad et al., 1983; Rudulier et al., 1984; Chandler and Thorpe, 1987; Paek et al., 1988; Kumar and Sharma, 1989; Jain et al., 1991b; Thomas et al., 1992; Verbruggen et al., 1993). Although investigated by many researchers, proline status of plant organs and cell cultures still continues to be an active area of research in stress physiology (Jain et al., 1991a). Effects of different osmotic, each with different physico-chemical properties, are yet to be critically addressed or compared. These compounds when treated in high concentrations produce shock-effects on tissues and are responsible for tissue damage, either permanent or temporary (Leone et al., 1994), depending on the tissues, adapted or unadapted. Damage may be due to leakage of osmotically active substances or due to loss of membrane functionality (Harrington and Alm, 1988). Proline, an osmotically active substance (Rains, 1989), may also be released from the cells due to shock. In the shock-treated tissues however, proline may be retained in certain cases and protect the cell viability (Fallon and Phillips, 1989). Implications related to proline production and its retention may be a point of physiological significance in experiments with stress-shocks. The most crucial function of irradiated plant cell is to respond to gamma stress by developing defines mechanisms. This defines may be affected by alteration in the pattern of gene expression (Corthals et al., 2000), which may led to modulation of certain metabolic and defensive pathways (Zolla et al., 2003). Owing to gene expression altered under gamma stress, qualitative and quantitative changes in total soluble protein contents were obvious in the study of Corthals et al. (2000). These proteins play an important role in signal transduction, antioxidative defines, antifreezing, heat shock, metal binding, antipathogenesis or osmolyte synthesis, which are essential to a plant's function and growth (Gygi et al., 1999; El-Fiki et al., 2003; El-Fiki et al., 2004).

Total genomic DNA from ten Nicotiana alata treatments were used as templates within RAPD finger printing. Five random decamer primers were used in the current study. The number of fragments amplified by each primer ranged between

Table 3. The combined effects of gamma radiation doses and $\mathrm{NaCl}$ concentrations on total soluble protein $(\mathrm{mg} / 100 \mathrm{~g}$ fresh wt) in haploid Nicotiana alata plants

\begin{tabular}{cccccc}
\hline \multirow{2}{*}{$\begin{array}{c}\mathrm{NaCl} \\
\text { conc/mM }\end{array}$} & 0 & 10 & 15 & 20 & 25 \\
\cline { 2 - 6 } 0.0 & 0.98 & 1.72 & 1.98 & 2.16 & 2.95 \\
50 & 1.13 & 1.81 & 0.89 & 1.92 & 1.14 \\
100 & 1.65 & 1.99 & 0.77 & 1.68 & 0.0 \\
150 & 2.11 & 2.17 & 0.62 & 0.0 & 0.0 \\
200 & 2.24 & 2.12 & 0.56 & 0.0 & 0.0 \\
\hline
\end{tabular}


1-13, with an average of 8.9 fragments per primer. Maximum numbers of bands (13) was produced by the primer OP-L12 (Fig. 3. D), whereas the minimum number of bands (1) was produced by the primer OP-I15 (Fig. 3. C). A representative RAPD profile was obtained with primers OP-I15 and OP-M20 (Fig. 3. C and E). The primer OP-L12 produced the maximum number of bands (13) in the salinity test and within the combined effect of salinity and gamma radiation; even more, among radiation treatments the same primer produced the maximum number of bands (12). The minimum number of bands was observed with primer OP-I15 (3, 3 and 1) in the irradiated, salt stress and combined effect of gamma radiation and salt stress plants respectively.

All tested primers were polymorphic. A total of 270 bands were amplified of which $226(83.7 \%)$ were polymorphic across the radiation treatments. The level of polymorphism among the salinity stress was $85.6 \%$, whereas, the polymorphism among the combined effects of gamma radiation and salinity was 85.5 $\%$ (Table 4).

\section{Treatments Specific Markers}

All tested primers except OP-I12 gave specific markers. A total of 11 treatments specific markers were generated. Radiation and salinity gave 4 specific markers each. However, 3 specific markers in the study of the combined effect between gamma irradiation and salinity were generated (Table 5). Among the 10 treatments were clearly differentiated by producing one or two specific bands with all the five primers used.

\section{Genetic relationships in treatments}

Common bands were scored as present, ambiguous, or absent and the data were used to calculate values of genetic distance between all the studied treatments. The results are given

Table 4. RAPD patterns generated for haploid Nicotiana alata under different treatments

\begin{tabular}{|c|c|c|c|c|c|c|}
\hline \multirow{4}{*}{$\begin{array}{c}\text { Primer } \\
\text { No. }\end{array}$} & \multicolumn{6}{|c|}{ Treatments } \\
\hline & \multicolumn{2}{|c|}{ Radiation } & \multicolumn{2}{|c|}{ Salinity } & \multicolumn{2}{|c|}{ Salinity x Radiation } \\
\hline & Total & No. polymorphic & Total & No. polymorphic & Total & No. polymorphic \\
\hline & No. band & band & No. band & band & No. band & band \\
\hline OP-C13 & 60 & $49(81.7 \%)$ & 48 & $40(83.3 \%)$ & 60 & $53(88.3 \%)$ \\
\hline OP-D07 & 55 & $51(92.77 \%)$ & 44 & $41(93.2 \%)$ & 55 & $50(90.9 \%)$ \\
\hline OP-I15 & 30 & $24(80 \%)$ & 24 & $20(83.3 \%)$ & 30 & $16(53.3 \%)$ \\
\hline OP-L12 & 65 & $57(88.77 \%)$ & 52 & $47(90.4 \%)$ & 65 & $62(95.4 \%)$ \\
\hline OP-M20 & 60 & $45(75 \%)$ & 48 & $37(77.1 \%)$ & 60 & $50(83.3 \%)$ \\
\hline Total & 270 & $226(83.7 \%)$ & 216 & $185(85.6 \%)$ & 270 & $231(85.51 \%)$ \\
\hline
\end{tabular}

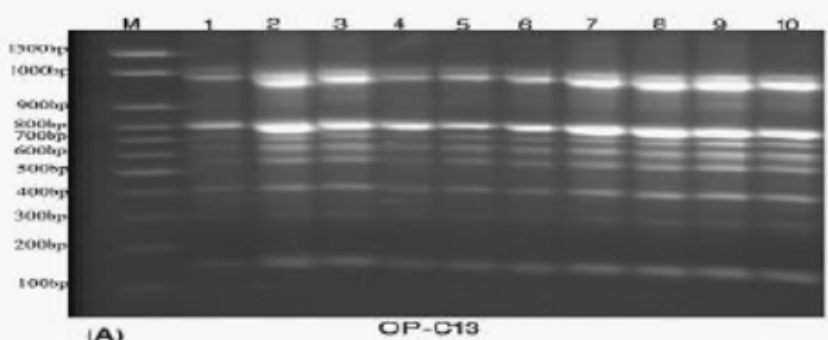

(A)

OP-C13

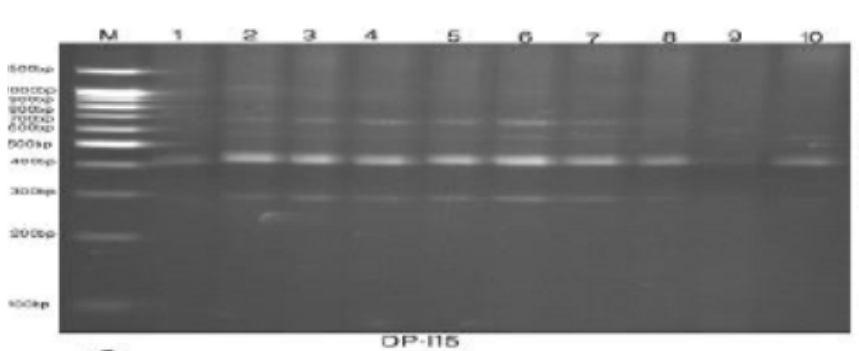

(C)
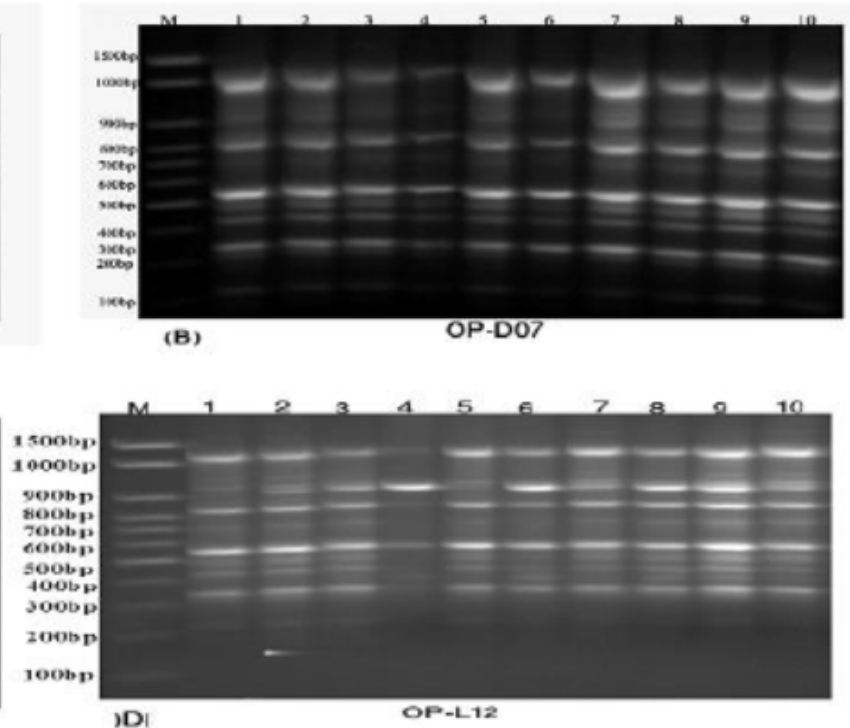

D|

OP-L12

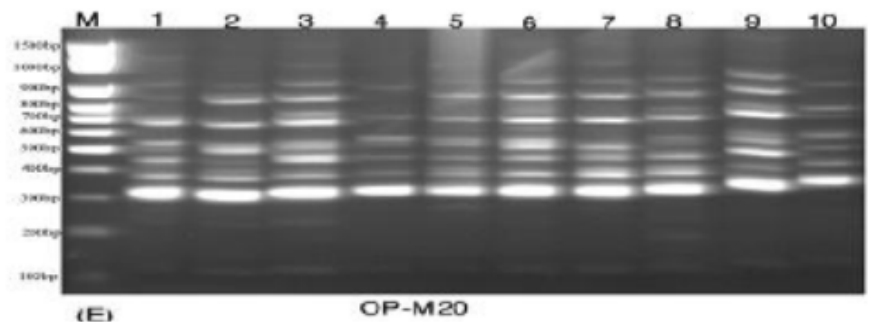

Fig. 3. Representative RAPD profile of treated haploid Nicotiana alata. Lane 1 Cont. diploid; Lane 2 Cont. haploid; Lane 3 Irradiated haploid 15 Gy; Lane 4 Irradiated haploid 20 Gy; Lane 5 Irradiated haploid 25 Gy; Lane 6 haploid Grew on 150 mM; Lane 7 haploid grew on $200 \mathrm{mM}$ NaCl; Lane 8 haploid 20 Gy X 50 mM NaCl; Lane 9 haploid 20 Gy X 100 mM NaCl; Lane 10 haploid 25 Gy 50 X 50 mM NaCl. 
78

Table 5. Used primers and the specific markers generated for salinity, radiation and combined treatments

\begin{tabular}{cc}
\hline Primer no. & $\begin{array}{c}\text { Specific marker } \\
\text { OP-C13 }\end{array}$ \\
\hline OP-D07 & $\begin{array}{c}1140 \text { badiation, } 1120 \mathrm{bp}-\text { salinity, } \\
\text { 1120bp-Radiation, } 1120 \mathrm{bp}, 680 \mathrm{bp}- \\
\text { combind effect }\end{array}$ \\
OP-I15 & $\begin{array}{c}\text { None } \\
\text { OP-L12 }\end{array}$ \\
OP-M20 & $\begin{array}{c}\text { 800,290bp-Ration, } 800 \mathrm{bp}, 525 \mathrm{bp}- \\
\text { salinity }\end{array}$ \\
\hline
\end{tabular}

in Table (4). The genetic distance scale run from 0 (identical) to 100 (different for all criteria studied hereby).The similarity index as shown in Table (6) revealed the maximum similarity of diploid with irradiated haploid with dose 20 Gy (similarity indices 1.0) while distantly related treatments were (20Gy $\times 50$ $\mathrm{mM} \mathrm{NaCl})$ with $(20 \mathrm{~Gy} \times 100 \mathrm{mM} \mathrm{NaCl})$ (similarity indices $0.0)$. The relationships within radiation treatments were $54 \%$, however these relationships within salinity treatments were $49 \%$, while in the combined effects between salinity and gamma radiation were $17 \%$.

\section{RAPD based genetic relationships}

All treatments of haploid Nicotiana alata have been separated into three main clusters; it was revealed that one cluster consisted of combined effects between salinity and gamma radiation and salinity treatments, the second one grouped gamma radiation treatments, with diploid and haploid plants, and the third one consisted of irradiated plants with $20 \mathrm{~Gy}$ and the haploid plants grown on $200 \mathrm{mM} \mathrm{NaCl}$. The treatments and the similarity between them in the first cluster were $(0.11)$, in the second cluster were $(0.56)$ and in third cluster were $(0.57)$ (Fig. 4).
The arbitrary nucleotide sequence, RAPD finger printing, is a frequently used technique for investigating genetic polymorphisms (Versalovic et al., 1994; Teaumroong and Boonkerd, 1998). RAPD markers have been used for numerous applications in plant molecular genetics research, despite having specific disadvantages of poor reproducibility and not generally being associated with gene regions (Welsh and McClelland, 1990; Williams et al., 1990). RAPD, being a multi locus marker (Karp et al., 1997) with the simplest and fastest detection technology, have been successfully employed for determination of intra species genetic diversity. Characterization and quantification of genetic diversity has long been a major goal in plant breeding as information on the genetic diversity within and among closely related crop species is essential for a rational use of genetic resources. The results showed that RAPD assay discriminated those flue-cure tobacco cultivars with similar genotypes. It seems that RAPD is an effective tool for flue-cured tobacco germplasm management, cultivar protection and cultivar improvement. The fragment polymorphism was higher than the one reported in the case of eggplant (10.28 bands per primer), which also belongs to the Solanaeceae family (Singh et al., 2005). The number of fragments amplified in $N$. tabacum was significantly higher than that reported earlier by Del Piano et al. (2000). A high degree of genetic polymorphism among 7 species of Nicotiana was also reported using AFLP (Ren and Timko, 2002). On the contrast, genetic diversity analysis by RAPD markers revealed $79 \%$ polymorphism among the species of $L$. peruvianum and very low (9\%) in the species $L$. peruvianum of the genus Lycopersicon (Kochieva et al., 2002). Species specific RAPD patterns have been developed and used to confirm hybridity in potato (Takemori et al., 1994) and intergeneric

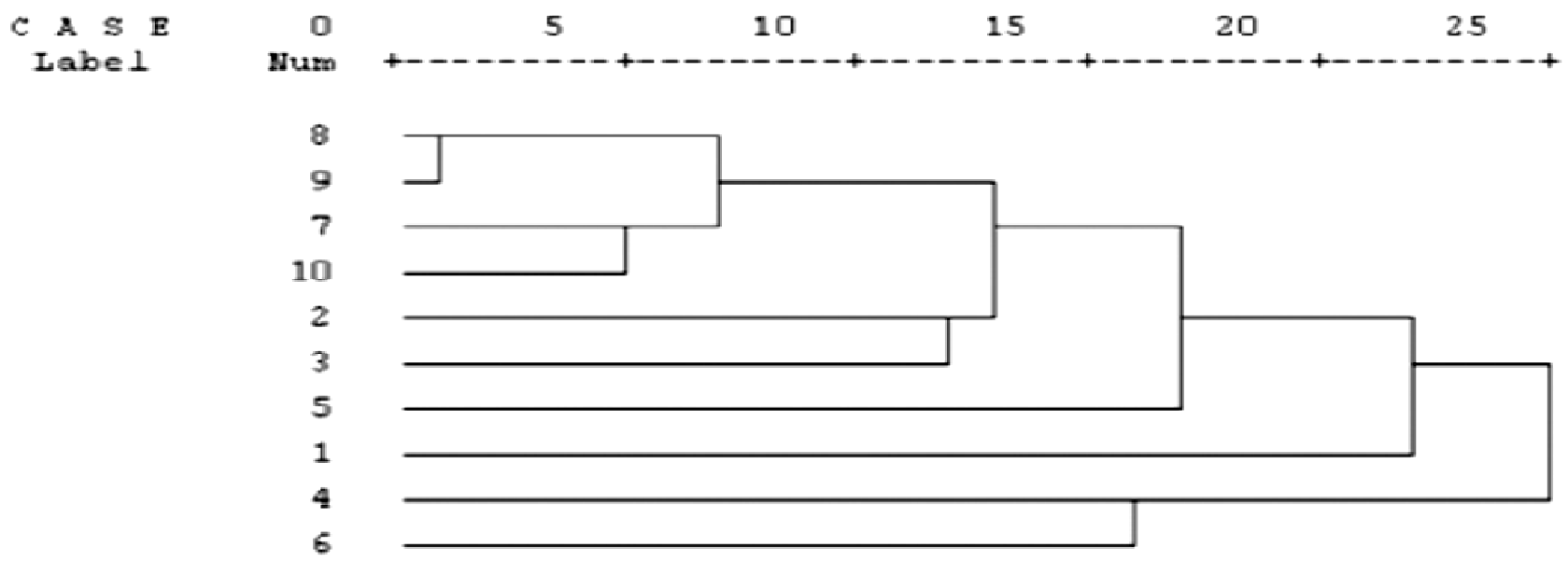

Fig. 4. A dendogram showing the genetic distance among ten treatments using RAPD data

Table 6. Similarity index (pairwise comparison) among the ten treatments based on RAPD analysis

\begin{tabular}{|c|c|c|c|c|c|c|c|c|c|}
\hline Treatments & 1 & 2 & 3 & 4 & 5 & 6 & 7 & 8 & 9 \\
\hline Haploid & 0.46 & & & & & & & & \\
\hline $15 \mathrm{~Gy}$ & 0.72 & 0.30 & & & & & & & \\
\hline 20 Gy & 1.0 & 0.79 & 0.66 & & & & & & \\
\hline $25 \mathrm{~Gy}$ & 0.47 & 0.31 & 0.56 & 0.54 & & & & & \\
\hline $150 \mathrm{mM} \mathrm{NaCl}$ & 0.73 & 0.43 & 0.31 & 0.41 & 0.57 & & & & \\
\hline $200 \mathrm{mM} \mathrm{NaCl}$ & 0.51 & 0.11 & 0.24 & 0.59 & 0.24 & 0.49 & & & \\
\hline $20 \mathrm{~Gy}$ x $50 \mathrm{mM} \mathrm{NaCl}$ & 0.53 & 0.37 & .037 & 0.87 & 0.50 & 0.63 & 0.18 & & \\
\hline $20 \mathrm{~Gy} \times 100 \mathrm{mM} \mathrm{NaCl}$ & 0.60 & 0.43 & .043 & 095 & 0.57 & 0.70 & 0.24 & 0.0 & \\
\hline $25 \mathrm{~Gy}$ x $50 \mathrm{mM} \mathrm{NaCl}$ & 0.59 & 0.30 & 0.30 & 0.66 & 0.43 & 0.56 & 0.11 & 0.12 & 0.17 \\
\hline
\end{tabular}


hybrids of Saccharum and Erianthus (Nair et al., 2002). Goodspeed (1954) had postulated that the present day assemblage of species was derived from a pregeneric genetic reservoir with three major components that had been designated pre- Nicotiana, pre-Cestrum and pre-Petunia. The Cestroid complex was thought to be ancestral to the Rustica whereas petunioides complex ancestral to the subgenus petunioides. Grouping of these species was clearly in accordance with the earlier classification based on traditional analysis of cytological and morphological characteristics.

\section{Conclusions}

The exposed haploid Nicotiana alata plants to radiation and salinity had a negative effect on the growth rate and the length of plants. While the combined effect between gamma rays and salinity was suffused on the growth rate and the length of the plants until the impact of certain treatments caused plant death. The present study would be useful for establishing molecular phylogeny in the species of Nicotiana. RAPD assay was also found effective in analyzing the polymorphism among treatments. The species specific markers identified would be utilized in future introgression breeding programs.

\section{Acknowledgement}

The research work was supported by grants from National Centre for Radiation Research and Technology, Egyptian Atomic Energy Authority.

\section{References}

Bai D, Reeleder R, Brandie JE (1995). Identification of two RAPD markers tightly linked with the Nicotiana debneyi genes for resistance to black root rot of tobacco. Theoretical and Applied Genetics 91(8):1184-1189.

Bates LS, Waldren RP, Teare ID (1973). Rapid determination of free proline for water stress studies. Plant and Soil 39:205-207.

Binzel ML, Hasegawa PM, Handa AK, Bressan RA (1985). Adaptation of tobacco cells to NaCl. Plant Physiology 79:118-125.

Bradford M (1976). A rapid and sensitive method for the quantitation of microgram quantities of protein utilizing the principle of proteindye binding. Analytical Biochemistry 27:248-254.

Bray EA (1997). Plant responses to water deficit. Trends in Plant Science 2:48-54.

Cellier F, Conéjéro G, Breitler J, Casse F (1998). Molecular and physiological responses to water deficit in drought-tolerant and drought-sensitive lines of sunflower. Plant Physiology 116(1):319338.

Chandler SF, Thorpe TA (1987). Characterization of growth, water relations, and proline accumulation in sodium sulfate tolerant callus of Brassica napus L. cv. Westar (Canola). Plant Physiology 84:106111.

Clegg MT (1990). Molecular diversity in plant populations, in plant population genetics, breeding and genetic resources. In: Brown AHD, Clegg MT, Kahler AL, Weir BS (Eds). Plant population genetics, breeding, and genetic resources. Sinauer Association Inc.
Corthals G, Gygi S, Aebersold R, Patterson SD (2000). Identification of proteins by mass spectrometry. Proteome Research 21(1):197-231.

Del Piano L, Abet M, Sorrentino C, Acanfora F, Cozzolino E (2000). Genetic variability in Nicotiana tabacum and Nicotiana species as revealed by RAPD procedure. Beiträge zur Tabakforschung / Contributions to Tobacco Research 19(1):1-15.

El-Fiki A, Sayed AIH, Abdel-Hameed AAM (2005a). The combined effect of gamma radiation and mannitol on callus formation and regeneration in alfalfa (Medicago sativa L.). International Journal Agriculture and Biology 7(6):966-972.

El-Fiki A, Sayed AIH, Abdel-Hameed AAM (2005b). Genotype, explant, medium, light and radiation effects on the in vitro plant regeneration in alfalfa (Medicago sativa $\mathrm{L}$.). Isotope and Radiation Research 37(2):437-453.

El-Fiki AA, Sayed AIH, Moustafa MAM (2004). Gamma radiation effects on growth and patterns of protein in organ and tissue culture of sweet potato (Ipomea batatas L. Lam). Arab Journal of Nuclear Science and Applications 37(3):253-263.

El-Fiki AAM (1997). Induction of genetic variability by using gamma radiation and selection for salt tolerance in vitro in potato (Solanum tuberosum). Journal of Genetics and Breeding 51:309-312.

Fallon KM, Phillips R (1989). Responses to water stress in adapted and unadapted carrot cell suspension cultures. Journal of Experimental Botany 40(215):681-687.

FAO (2008). Land and plant nutrition management service. Available online at: $h$ ttp://www.fao.org/ag/agl/agll/spush/. Accessed 25 April 2008.

Ghassemi F, Jakeman AJ, Nix HA (1995). Salinization of land and water resources. University of New South Wales Press, Canberra.

Goodspeed TH (1954). The genus Nicotiana. Chronica Botanica 16.

Grant RF, Jackson BS, Kiniry JR, Arkin GF (1989). Water deficit timing effects on yield components in maize. Agronomy Journal 81:61-65.

Gwanama C, Labuschagne MT, Botha AM (2002). Analysis of genetic variation in Cucurbita moschata by random amplified polymorphic DNA(RAPD) markers. Euphytica 113:19-24.

Gygi SP, Rochon Y, Franza BR, Aebersold R (1999). Correlation between protein and mRNA abundance in yeast. Molecular and Cellural Biology 19(1):1720-1730.

Handa S, Handa AK, Hasegawa PM, Bressan RA (1986). Proline accumulation and the adaptation of cultured plant cells to water stress. Plant Physiology 80:938-945.

Harrington HM, Alm DM (1988). Interaction of heat and salt shock in cultured tobacco cells. Plant Physiology 88:611-625.

Hasegawa H, Takashima S, Nakamura A (1995). Effect of gamma ray irradiation on cultured anthers of tobacco (Nicotiana tabacum L.) radiosensitivity and morphological variants appearing in the haploid plants. Plant Tissue Culture Letters 12(3):281-287.

Hasegawa PM, Bressan RA, Zhu JK, Bohnert HJ (2000). Plant cellular and molecular responses to high salinity. Annual Reviews Plant Physiology Plant Molecular Biology 51:463-499.

Jain RK, Jain S, Chowdhury JB (1991a). In vitro selection for salt tolerance in Brassica juncea L. using cotyledon explants, callus and cell suspension cultures. Annals of Botany 67:517-519. 
80

Jain S, Nainawatee HS, Jain RK, Chowdhury JB (1991b). Proline status of genetically stable salt tolerant Brassica juncea L. somaclones and their parent cv. Prakash. Plant Cell Reports 9:684-687.

Karp A, Nelson RS, Thomas E, Bright SWJ (1997). Chromosome variation in protoplast- derived potato plants. Theoretical and Applied Genetics 63:265-272.

Kim JH, Baek MH, Chung BY, Wi SG, Kim JS (2004). Alterations in the photosynthetic pigments and antioxidant machineries of red pepper (Capsicum annum L.) seedlings from gamma irradiated seeds. Journal of Plant Biology 47(2):314-321.

Kiong ALP, Lai AG, Hussein S, Harun A (2008). Physiological responses of Orthosiphon stamineus plantles to gamma irradiation. AmericanEurasian Journal of Sustainable Agriculture 2(2):135-149.

Kochieva EZ, Ryzhova NN, Khrapalova IA, Pukhal VA (2002). Using RAPD for estimating genetic polymorphism in and phylogenetic relationships among species of the genus Lycopersicon (Toum.)Mill. Genetika 38:1298-1306.

Kovacs E, Keresztes A (2002). Effect of gamma and UV-B/C radiation on plant cells. Micron 33(4):199-210.

Kumar V, Sharma DR (1989). Isolation and characterization of sodium chloride-resistant callus cultures of Vigna radiata (L.) Wilczek var. radiata. Journal of Experimental Botany 40(210):143-147.

Leone A, Costa A, Tucci M, Grillo S (1994). Adaptation versus shock response to polyethylene glycol-induced low water potential in cultured potato cells. Physiologia Plantarum 92:21-30.

Lerner HR (1985). Adaptation to salinity at the plant-cell level. Plant Soil 89:3-14.

Murashige T, Skoog F (1962). A revised medium for rapid growth and bio assay with tobacco tissue cultures. Physiologia Plantarum 15:473-497.

Nair VN, Selvi A, Sreenivasan TV, Pushpalatha KN (2002). Molecular diversity in Indian sugarcane cultivars as revealed by Random amplified DNA polymorphisms, Euphytica 127:219-225.

Norfadzrin F, Ahmed OH, Shaharudin S, Abdul Rahman D (2007). A preliminary study on gamma radiosensitivity of tomato and okra. International Journal of Agricultural and Research 2(7):620-625.

Ortiz A, Renaud R, Calzada I, Ritter R (1997). Analysis of plum cultivars with RAPD markers. Journal of Horticultural Science 72:1-9.

Paek KY, Chandler SF, Thorpe TA (1988). Physiological effects of $\mathrm{Na} 2 \mathrm{SO} 4$ and $\mathrm{NaCl}$ on callus cultures of Brassica campestris (chinese cabbage). Physiologia Plantarum 72:160-166.

Rains DW (1989). Plant tissue and protoplast culture: Applications to stress physiology and biochemistry. In: Jones HG, Flowers TJ, Jones MB (Eds). Plants under Stress. Society for Experimental Biology, seminar series 39, Cambridge University Press.

Randade SA, Verma A, Gupta M, Kumar N (2002). RAPD profile analysis of betel vine cultivars. Biologia Plantarum 45:523-527.

Rohlf FJ (1990). NTSYS-pc numerical taxonomy and multivariate analysis system. Version 2.1 (Exter software, Setauket, New York).

Rout GR, Das G (2002). An assessment of genetic integrity of micropropagated plants of Plumbago zeylanica by RAPD markers. Biologia Plantarum 45:27-32.

Rudulier DL, Strom AR, Dandekar AM, Smith LT, Valentine RC (1984). Molecular biology of osmoregulation. Science 224:1064 1068 .
Rufty R, Yi YH, Wernsman EA (1997). RAPD markers linked to wild fire resistance in tobacco identified through bulked segregant analysis. Bulletin Coresta, Montreal, Abstract AP 63:50.

Samal, S, Rout, GR, Nayak S, Nanda RM, Lenka PC, Das P (2003). Primer screening and optimization for RAPD analysis of cashew. Biologia Plantarum 46:301-304.

Singh AK, Singh M, Singh AK, Singh R, Kumar S, Kalloo G (2005). Genetic diversity within the genus Solanum (Solanaceae) as revelled by RAPD markers. Current Science 90:711-716.

Takemori N, Shinoda K, Kadotani N (1994). RAPD markers for confirmation of somatic hybrids in the dihaploid breeding of potato. Plant Cell Reports 13:367-371.

Teaumroong N, Boonkerd N (1998). Detection of Bradyrbizobium spp. and Bjaponicum in Thailand by primer based technology and direct DNA extraction. Plant and Soil 204:127-134.

Teaumroong N, Boonkerd N (1998). Detection of Bradyrbizobium spp. and B. japonicum in Thailand by primer-based technology and direct DNA extraction. Molecular Microbial Ecology of the Soil pp 127-134. Springer Netherlands.

Thomas JC, De Armond RL, Bohnert HJ (1992). Influence of $\mathrm{NaCl}$ on growth, proline and phosphoenol pyruvate caxboxylase levels in Mesembryanthemum crystallinum suspension cultures. Plant Physiology 98:626-631.

Verbruggen N, Villarroel R, Montagu MV (1993). Osmoregulation of a pyrroline-5-carboxylate reductase gene in Arabidopsis thaliana. Plant Physiology 103:771-781.

Versalovic J, Schneider M, de Bruijn FJ, Lupski JR (1994). Genomic fingerprinting of bacteria using repetitive sequence based polymerase chain reaction. Methods in Molecular and Cellular Biology 5:25-40.

Watad AEA, Reinhold L, Lerner HR (1983). Comparison between a stable $\mathrm{NaCl}$ selected Nicotiana cell line and the wild type. Plant Physiology 73:624-629.

Welsh J, McClelland M (1990). Fingerprinting genomes using PCR with arbitrary primers. Nucleic Acids Research 18:7213-7218.

Wi SG, Chung BY, Kim JH, Baek MH, Yang DH, Lee JW, Kim JS (2005). Ultrastructural changes of cell organelles in Arabdopsis stem after gamma irradiation. Journal of Plant Biology 48(2):195-200.

Williams JGK, Kubelik AR, Livak KJ, Rafalski JA, Tingey SV (1990). DNA polymorphisms amplified by arbitrary primers are useful as genetic markers. Nucleic Acids Reserch 18:6531-6535.

Yancey PH, Clark ME, Hand SC Bowlus RD, Somero GN (1982). Living with water stress: evolution of osmolyte systems. Science 217:1214-1222.

Yi HY, Rufty RC, Wernsman EA (1998). Mapping root knot nematode resistance gene $(\mathrm{RK})$ in tobacco with RAPD markers. Plant Disease 82:1319-1322.

Zhang HY, Liu XZ, Wei L, Zhou LY, Yang YM (2007). Insect resistant transgenic tobacco plants containing both $\mathrm{B}$. T. and GNA genes. Biologia Plantarum 51:746-748.

Zhu J 2000. Genetic analysis of plant salt tolerance using Arabidopsis. Plant Physiology 124(3):941-957.

Zolla L, Timperio AM, Walcher W, Huber CG (2003). Proteomics of light harvesting proteins in different plant species. Plant Physiology 131(2):198-214. 